\title{
A varixeredetü gastrointestinalis vérzés ellátásának változása osztályunkon
}

\author{
Rácz Sándor dr. - Molnár Péter dr. - Héra László dr. - Újhelyi Piroska dr. \\ Páll István dr. - Sebők Andrea dr. - Sahin Péter dr.
}

Jahn Ferenc Dél-pesti Kórház és Rendelőintézet, Gasztroenterológiai Osztály, Budapest

Bevezetés: A nyelőcső-varixruptura a portalis hypertensio életet veszélyeztető szövődménye. A 6 hetes mortalitás kb. $20 \%$.

Célkitüzés: Annak elemzése, hogy a varixeredetű gastrointestinalis vérzés ellátásában a 2015-ben osztályunkon bevezetett változások hatással voltak-e ezen betegek kórházi halálozására.

Módszer: Retrospektív módszerrel hasonlítottuk össze a 2014-ben és 2015-ben ellátott varixvérző betegek adatait. 2015-ben a varixvérző betegek ellátásában két változtatás történt: szubintenzív ellátóegységben láttunk el minden beteget, és minden, varixvérzésre gyanús betegnél alkalmaztunk terlipresszint. A vérzéscsillapítás sclerotherapiával és/vagy ligatióval történt. A szignifikanciát Student-féle t-próbával számoltuk. A betegek adatai 2014 vs. 2015: betegszám: 24 vs. 30 , átlagéletkor: 59,8 vs. 57,6 év, férfi (\%): 70,8 vs. 66,7. A Child-Pugh-stádiumokban nem volt szignifikáns különbség a két év között, $\mathrm{p}=0,53$. A betegeket úgy is csoportosítottuk az elemzéskor, hogy az ellátás évétől függetlenül kaptak-e terlipresszint vagy sem. Ekkor az adatok: betegszám: 22 vs. 32, átlagéletkor: 60,4 vs. 57,4 , férfi (\%): 63,6 vs. 70,6 .

Eredmények: A mortalitás 2015-ben 23\%, 2014-ben 33\% volt! A terlipresszint kapó és nem kapó betegek halálozása: $18,2 \%$ vs. $34,4 \%, p=0,09$. A kórházi mortalitást a legerősebben befolyásoló tényező a beteg felvételkori Child-Pughstádiuma (A- vs. B-stádium p =0,05, A- vs. C-stádium p =0,02). A Child-Pugh-féle C-stádiumú betegeknél alkalmazott terlipresszinterápia mortalitáscsökkentő hatása a szignifikancia határán volt $(\mathrm{p}=0,055)$.

Köpetkeztetés: Osztályunkon az elmúlt évben a varixeredetü gastrointestinalis vérzések ellátásában bevezetett változások a viszonylag kis esetszámok mellett is lényeges mortalitáscsökkenéshez vezettek.

Orv Hetil. 2020; 161(15): 583-587.

Kulcsszavak: varixvérzés, terlipresszin, halálozás, májzsugor, szubintenzív részleg

\section{Changes in the management of variceal gastrointestinal haemorrhage in our department}

Introduction: Variceal bleeding is a life-threatening complication of portal hypertension with a six-week mortality rate of approximately $20 \%$.

Aim: To analyse whether the changes introduced in the treatment of variceal gastrointestinal haemorrhage in our department affected the mortality rate of these patients.

Method: A retrospective method was used to compare the data of patients treated with variceal bleeding in 2014 and 2015. In 2015, two changes were made in the treatment of patients with variceal bleeding: all patients were treated in the subintensive care unit and terlipressin was administered to all patients susceptible to variceal haemorrhage. Bleeding was mitigated by means of sclerotherapy and/or ligation. Significance was calculated using Student's t-test, then we performed logistic regression to find out what treatment factors affect mortality rate. Patients: 2014 vs. 2015 figures - number of patients: 24 vs. 30 , average age: 59.8 vs. 57.6 years, male (\%): 70.8 vs. 66.7 . There were no significant differences between the Child-Pugh stages of the two years, $\mathrm{p}=0.53$. For the analysis we also grouped patients based on whether irrespective of the year of treatment they were administered terlipressin or not. Number of patients: 22 vs. 32 , average age: 60.4 vs. 57.4 , male (\%): 63.6 vs. 70.6 .

Results: Mortality in 2015 and 2014: 23\% and 33\%, respectively. Mortality of patients treated with terlipressin: 18.2 vs. $34.4, \mathrm{p}=0.09$. Child-Pugh stages had the strongest influence on mortality (stage A vs. B p $=0.05$, stage A vs. C $\mathrm{p}=0.02$ ). Terlipressin administered in Child-Pugh stage $\mathrm{C}$ reduced mortality at a rate bordering on significance $(\mathrm{p}=0.055)$.

Conclusion: Despite the comparatively small number of cases, the changes introduced in our department in 2015 in the treatment of variceal gastrointestinal haemorrhages resulted in a significant reduction of hospital mortality rates. 
Keywords: variceal bleeding, terlipressin, mortality, cirrhosis, subintensive care

Rácz S, Molnár P, Héra L, Újhelyi P, Páll I, Sebők A, Sahin P. [Changes in the management of variceal gastrointestinal haemorrhage in our department]. Orv Hetil. 2020; 161(15): 583-587.

(Beérkezett: 2019. szeptember 30.; elfogadva: 2020. január 11.)

\section{Rövidítések}

EKG = elektrokardiográfia; TIPS = transjugularis intrahepaticus portosystemás shunt

A nyelőcső-varixruptura a portalis hypertensio életet veszélyeztető szövődménye. A 6 hetes mortalitás jelenleg is $20 \%$ körül van $[1,2]$. A varixvérző betegek ellátásának alapvető lépései a vénabiztosítás, a folyadékresuscitatio a keringési paraméterek stabilizálására, a monitorozás megkezdése, szükség esetén légútbiztosítás intubációval. Amennyiben az elvesztett vérmennyiség indokolttá teszi, transzfúzió adása is szükséges (cél-hemoglobinérték: $70-80 \mathrm{~g} / 1)[3,4]$. Antibiotikumprofilaxis adása is szükséges kinolon vagy intravénás ceftriaxon adásával [5]. A fenti általános kezelési módszerek mellett specifikus gyógyszeres kezelés is szükséges vazoaktív szerek alkalmazásával (oktreotid, szomatosztatin, terlipresszin, vazopresszin). Ezek a gyógyszerek csökkentik a portalis vérátáramlást, a varixokban uralkodó nyomást. Ezáltal növelik a primer haemostasis arányát, csökkentik a mortalitást. A vazoaktív szer alkalmazását követően kell, hogy sor kerüljön endoszkópos beavatkozásra 12 órán belül. Az endoszkópos vérzéscsillapítási módszerek közül elsőnek választandó a ligatio, akut vérzésben és szekunder profilaxisban egyaránt. Előnye a többi módszerhez képest, hogy gyorsabban szünteti meg a vérzést, alkalmazása kevesebb szövődménnyel jár, az újravérzés aránya kisebb, és a mortalitás is kedvezőbb. Sclerotherapia alkalmazása akkor jön szóba, ha a ligatio technikailag nehézkes, nem kivitelezhető (például rossz látási viszonyok miatt), illetve subcardialis varixok esetében.

Sikertelen vérzéscsillapítás esetén átmenetileg ballontamponád jön szóba, majd ismételt endoszkópia vagy transjugularis intrahepaticus portosystemás shunt (TIPS) [6-8]. Átmeneti megoldásként a vérzés csillapítására újabban speciálisan erre a célra kialakított, bevont nyelőcső fémsztentek is alkalmazhatók [9]. A vérzés másodlagos megelőzésére ismételt ligatio és nem szelektív bétablokkoló együttes alkalmazása a leghatékonyabb [10]. Jelen vizsgálatunk célja az volt, hogy a varixeredetú gastrointestinalis vérzés ellátásában a 2015-ben osztályunkon bevezetett változások hatással voltak-e ezen betegek kórházi halálozására.

\section{Módszer}

Retrospektív módszerrel hasonlítottuk össze a 2014-ben és 2015-ben osztályunkon ellátott, nyelőcsővarix-eredetû vérzésben szenvedő betegek adatait. Gyomorvarixos beteget nem vettünk be a vizsgálatba, tekintettel arra, hogy a gyomorvarixok ellátása a nyelőcsővarixokétól eltérő, speciális endoszkópos vérzéscsillapítási módszert igényel (Histoacryl szövetragasztásos sclerotherapia) ezeket más intézményben végezték el. 2015 áprilisától a varixvérző betegek ellátásában két változtatás történt osztályunkon: egyrészt az újonnan megnyílt szubintenzív ellátóegységben látunk el minden beteget, másrészt minden, varixvérzésre gyanús (anamnézis alapján ismert vagy klinikai jelek alapján feltételezhetően májcirrhosisban szenvedő beteg felső tápcsatornai vérzés tüneteivel) esetnél alkalmaztunk terlipresszint. A 4 ággyal rendelkező szubintenzív részlegen folyamatos EKG-monitorizálás, pulzoximetria, meghatározható időintervallummal automatikus noninvazív vérnyomásmérés végezhető. Rendelkezésre áll infúzió- és vérmelegítő, gyógyszeradagoló perfúzor, központi oxigén és vákuum, újraélesztéshez szükséges felszerelés. A részlegen a vérző betegek ellátásában gyakorlott gasztroenterológus szakorvosok és nővérek dolgoznak. Ezáltal a betegek állapotváltozása szorosan nyomon követhető, a szükséges beavatkozások a lehető leghamarabb szakszerúen elvégezhetők. A terlipresszint az alábbi protokoll szerint alkalmaztuk: varixvérzés gyanúja esetén azonnal $2 \mathrm{mg}$, majd 24 órán keresztül 4 óránként $2 \mathrm{mg}$ intravénás bolusban. Az urgens endoszkópos vizsgálat minden esetben 24 órán belül megtörtént. Mivel a definitív ellátásra szolgáló endoszkópos vérzéscsillapítás 24 órán belül megtörtént, finanszírozási korlátok miatt további terlipresszinterápiát nem alkalmaztunk. A terlipresszinterápia leállítását követően - amennyiben ellenjavallat nem volt - nem kardioszelektív béta-blokkoló kezelésben részesültek a betegek. $\mathrm{Az}$ endoszkópos vérzéscsillapítás sclerotherapiával és / vagy ligatióval történt. A sclerotherapia és ligatio együttes alkalmazására akkor került sor, ha a megkezdett ligaturás kezeléssel nem sikerült a vérzést elállítani. Azokban az esetekben, amelyekben endoszkópos terápiával nem sikerült a vérzést megállítani, illetve a masszív vérzés okozta rossz látási viszonyok miatt endoszkópos terápia nem volt végezhető, szondatamponád alkalmazására került sor. TIPS, illetve fémsztent nem került alkalmazásra. A varixvérzés gyanújával felvett betegek az endoszkópia előtt antibiotikum (ceftriaxon $2 \mathrm{~g}$ iv.) adásában részesültek. A vizsgált időszakokban intravénás eritromicinkészítmény osztályunkon nem állt rendelkezésre, így ennek adására az endoszkópiákat megelőzően nem került sor. A betegeket úgy is csoportosítottuk, hogy az ellátás évétől függetlenül kaptak-e terlipresszint vagy sem. A szignifikanciát Student-féle t-próbával számoltuk. 


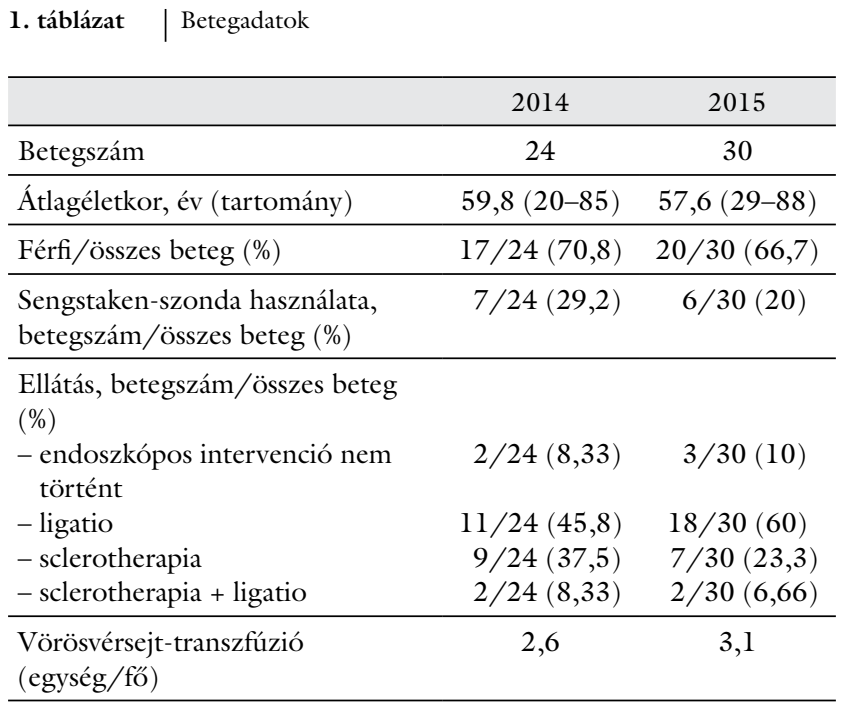

\section{Eredmények}

Az 1. táblázatban láthatók a 2014-ben és 2015-ben ellátott betegek adatai. 2014-ben 24 beteget láttunk el, átlagéletkoruk 59,8 év volt (a legfiatalabb 20 éves, a legidősebb 85 éves volt). A férfiak aránya $70,8 \%$ volt (17/24 beteg), Sengstaken-szonda használatára 29,2\%-ban került sor $(7 / 24$ beteg). Endoszkópos intervenció nem történt a betegek $8,33 \%$-ában $(2 / 24$ beteg). Ligaturás kezelés történt az esetek 45,8\%-ában (11/24 beteg), sclerotherapiát 37,5\%-ban alkalmaztunk $(9 / 24$ beteg). Sclerotherapia és ligatio együttes alkalmazására az esetek $8,33 \%$-ában került sor $(2 / 24$ beteg). Az l före jutó vörösvérsejt-transzfúziós igény átlagosan 2,6 egység volt. A betegek 70,8\%-a (17/24 beteg) volt első alkalommal varixvérzés miatt ellátva, 29,2\%-uk (7/24 beteg) varixvérzés miatt már korábban is ellátásban részesült.

2015-ben 30 beteget láttunk el, átlagéletkoruk 57,6 év volt (a legfiatalabb 29 éves, a legidősebb 88 éves volt). A férfiak aránya $66,7 \%$ volt $(20 / 30$ beteg), Sengstakenszonda használatára 20\%-ban került sor $(6 / 30$ beteg). Endoszkópos intervenció nem történt a betegek $10 \%$ ában $(3 / 30$ beteg). Ligaturás kezelés történt az esetek $60 \%$-ában ( $18 / 30$ beteg), sclerotherapiát 23,3\%-ban alkalmaztunk ( $7 / 30$ beteg). Sclerotherapia és ligatio együttes alkalmazására az esetek 6,66\%-ában került sor (2/30 beteg). Az l fớre jutó vörösvérsejt-transzfúziós igény átlagosan 3,1 egység volt. A betegek 50\%-a (15/30 beteg) volt első alkalommal varixvérzés miatt ellátva, $50 \%$-uk ( $15 / 30$ beteg) varixvérzés miatt már korábban is ellátásban részesült.

2014-ben a betegek Child-Pugh-stádiumok szerinti megoszlása a következő volt: A-stádium 33,3\% (8/24 beteg), B-stádium $45,8 \%$ (11/24 beteg), C-stádium 20,8\% (5/24 beteg). 2015-ben a betegek Child-Pughstádiumok szerinti megoszlása: A-stádium 50\% (15/30 beteg), B-stádium 26,7\% (8/30 beteg), C-stádium $23,3 \%$ (7/30 beteg). A két év között a betegek Child-
2. táblázat A betegek csoportosítása aszerint, hogy kaptak-e terlipresszint vagy nem (az ellátás évétól függetlenül)

\begin{tabular}{lcc}
\hline & $\begin{array}{c}\text { Terlipresszint } \\
\text { kaptak }\end{array}$ & $\begin{array}{c}\text { Terlipresszint } \\
\text { NEM kaptak }\end{array}$ \\
\hline Betegszám & 22 & 32 \\
\hline Átlagéletkor, év (tartomány) & $60,4(29-88)$ & $57,4(20-85)$ \\
\hline Férfi/összes beteg (\%) & $14 / 22(63,6)$ & $23 / 32(70,6)$ \\
\hline
\end{tabular}

Pugh-stádiumában nem volt szignifikáns különbség. Azon betegeknél nem történt endoszkópos intervenció az endoszkópia során, akiknél a masszív vérzés okozta rossz látási viszonyok miatt nem volt végezhetô vérzéscsillapító beavatkozás, vagy a betegek elhunytak, mielött az endoszkópos intervencióra sor kerülhetett volna.

A 2. táblázatban a betegeket aszerint csoportosítottuk, hogy az ellátás évétól függetlenül kaptak-e terlipresszint vagy sem. A terlipresszinterápiában részesült betegek száma 22 volt, átlagéletkoruk 60,4 év (a legfiatalabb 29 , a legidősebb 88 éves volt), a férfiak aránya $63,6 \%$ volt (14/22 beteg), a varixvérzés miatt első alkalommal ellátott betegek aránya $54,5 \%$ (12/22 beteg). A terlipresszinterápiában nem részesült betegek száma 32 volt, átlagéletkoruk 57,4 év (a legfiatalabb 20 éves, a legidősebb 85 éves volt), a férfiak aránya $70,6 \%$ volt (23/32 beteg), a varixvérzés miatt első alkalommal ellátott betegek aránya $62,5 \%(20 / 32$ beteg $)$. A terlipreszszinterápiában részesült betegek Child-Pugh-stádiumok szerinti megoszlása: A-stádium $54,5 \%$ (12/22 beteg), B-stádium 27,3\% (6/22 beteg), C-stádium 18,2\% (4/22 beteg). A terlipresszinterápiában nem részesült betegek megoszlása: A-stádium 34,4\% (11/32 beteg), B-stádium $40,6 \%$ (13/32 beteg), C-stádium 25\% (8/32 beteg). A Child-Pugh-stádiumok között a két csoportban itt sem volt szignifikáns eltérés.

2014-ben a kórházi mortalitás 33\% volt, míg 2015ben $23 \%$. A kórházi mortalitás $10 \%$-kal csökkent! Az 1. ábra alapján látható, hogy a terlipresszinterápiában nem részesülő betegek halálozási aránya $34,4 \%$ volt, a terlipresszinterápiában részesülőké $18,2 \%$. A két csoport Child-Pugh-stádiumok szerinti halálozási adatait a 2. ábra szemlélteti. A kórházi mortalitást a legerősebben befolyásoló tényező a beteg felvételkori Child-Pugh-stádiuma volt (mindkét csoportban $\mathrm{A}$ - vs. B-stádium $\mathrm{p}=$ $0,05, A$ - vs. C-stádium $p=0,02)$. A Child-Pugh-féle C-stádiumú betegeknél alkalmazott terlipresszinterápia mortalitáscsökkentő hatása a szignifikancia határán van $(\mathrm{p}=0,055)$.

\section{Megbeszélés}

Adataink azt mutatják, hogy az osztályunkon a varixeredetû gastrointestinalis vérzések ellátásában bevezetett változások lényeges kórházi mortalitáscsökkenéshez vezettek. A viszonylag kis esetszámokkal magyarázható, hogy az eredmények a szignifikancia határát csak közelí- 


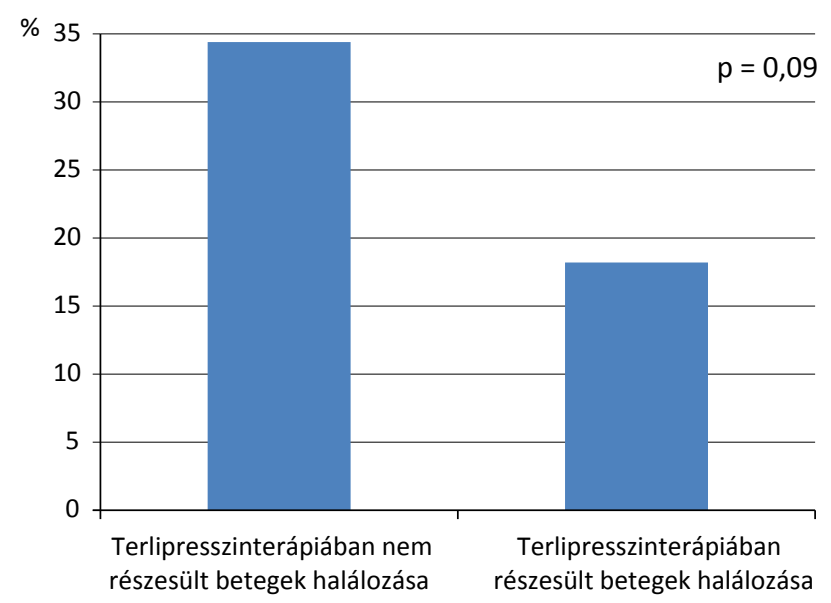

1. ábra $\quad$ A kórházi halálozás összehasonlítása terlipresszint kapott és nem kapott betegeknél

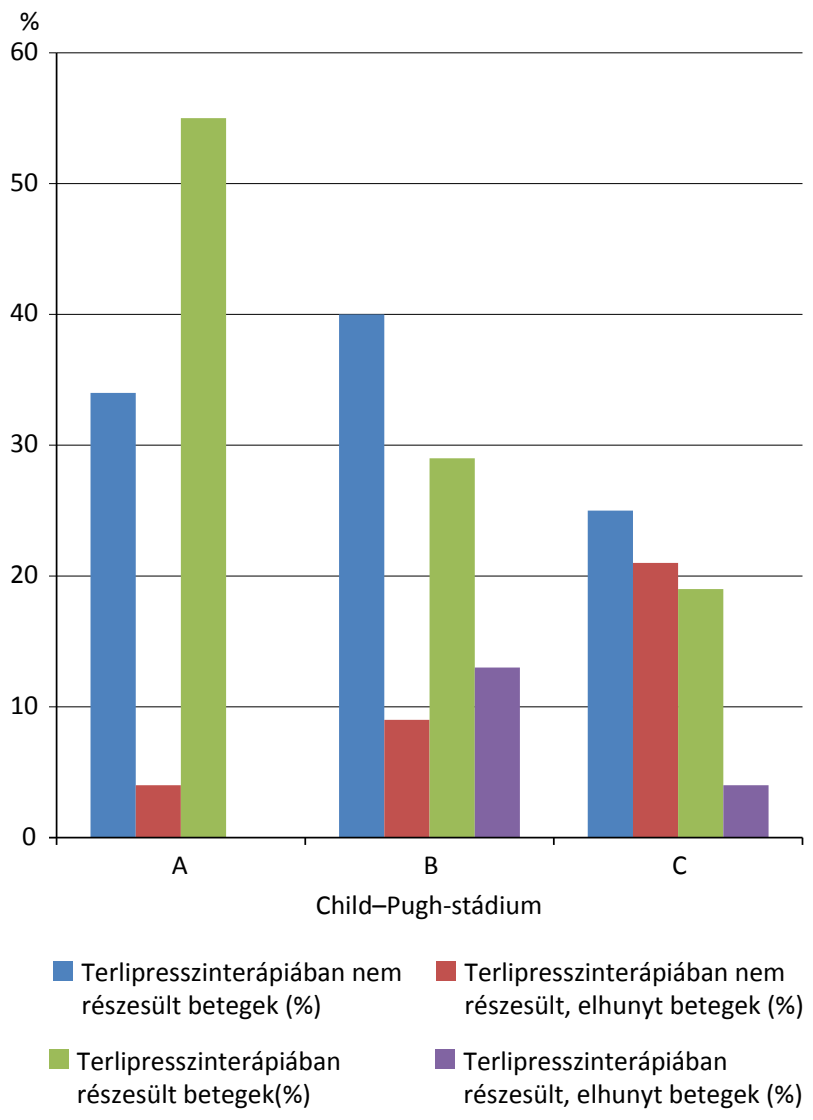

2. ábra | A halálozási arány a Child-Pugh-stádiumok szerint

tik. Az irodalmi adatok alapján a cirrhosisban szenvedő betegek első varixvérzésének halálozási aránya jelenleg is 15-20\%, a Child-Pugh-féle C-stádiumú betegeknél a $30 \%$-ot is eléri [11]. Ennek alapján a nálunk elért 18,2\%os halálozási arány megfelel a nemzetközi szintnek. A csökkent halálozás magyarázataként említhető a szubintenzív részlegen alkalmazott szoros obszerváció és adekvátabb terápia. A terlipresszinterápiában részesülő betegek csoportjában a több sikeres endoszkópos terá- pia, kevesebb szondatamponád alkalmazása szintén a túlélést javíthatja. Noha irodalmi adatok alapján a terlipresszin alkalmazása a transzfúziós igényt csökkenti, vizsgálatunkban mégis azt tapasztaltuk, hogy a terlipresszinterápiában részesült csoportban átlagosan több vörösvérsejt-koncentrátum adására került sor. Feltételezésünk szerint ebben közrejátszhat az is, hogy a több túlélő beteg hemoglobinszintjének megfelelő tartományba történő rendezése további transzfúziókat igényelt.

Vizsgálatunk korlátaként említhető, hogy a halálozást befolyásoló valamennyi paraméter (például a társbetegségek jelenléte) nem állt rendelkezésre. Nemzetközi guideline-ok a vazoaktív szerek adását 2-5 napig javasolják, azonban arra is vannak adatok, hogy rövidített idejü alkalmazás esetén is jelentős javulás érhető el a betegek túlélésében $[12,13]$. Tekintettel arra, hogy a hazai finanszírozási rendszerben a vazoaktív terápia nincs külön finanszírozva, a rövidebb idejű alkalmazásnak is jelentős szerepe lehet a betegek túlélésének javításában. Következtetésként levonható, hogy a gastrointestinalis vérzést ellátó centrumok mindegyikében szükséges lenne a terlipresszin használata, valamint a szubintenzív ellátási forma alkalmazása is.

Anyagi támogatás: A közlemény megírása, illetve a kapcsolódó kutatómunka anyagi támogatásban nem részesült.

Szerzői munkamegosztás: R. S.: Irodalomkutatás, adatgyưjtés, adatelemzés, a kézirat megírása. M. P., H. L., Ú. P., P. I.: Adatgyújtés. S. A.: S. P.: A kutatómunka megtervezése, adatgyűjtés, adatelemzés, az ábrák elkészítése. A cikk végleges változatát valamennyi szerző elolvasta és jóváhagyta.

Érdekeltségek: A szerzőknek nincsenek érdekeltségeik.

\section{Köszönetnyilvánítás}

Köszönjük Csillag Mártonnak a statisztikai számítások elvégzéséhez nyújtott segítségét.

\section{Irodalom}

[1] Triantos C, Kalafateli M. Endoscopic treatment of esophageal varices in patients with liver cirrhosis. World J Gastroenterol. 2014; 20: 13015-13026.

[2] Fortune B, Garcia-Tsao G. Current management strategies for acute esophageal variceal hemorrhage. Curr Hepatol Rep. 2014; 13: 35-42.

[3] Kim YD. Management of acute variceal bleeding. Clin Endosc. 2014; 47: 308-314.

[4] Satapathy SK, Sanyal AJ. Non-endoscopic management strategies for acute esophagogastric variceal bleeding. Gastroenterol Clin North Am. 2014; 43: 819-833.

[5] Lee YY, Tee HP, Mahadeva S. Role of prophylactic antibiotics in cirrhotic patients with variceal bleeding. World J Gastroenterol. 2014; 20: 1790-1796. 
[6] Seo YS. Prevention and management of gastroesophageal varices. Clin Mol Hepatol. 2018; 24: 20-42.

[7] Hwang JH, Shergill AK, Acosta RD, et al. The role of endoscopy in the management of variceal hemorrhage (ASGE guideline). Gastrointest Endosc. 2014; 80: 221-227.

[8] de Franchis R, on behalf of the Baveno V Faculty. Revising consensus in portal hypertension: report of the Baveno $\mathrm{V}$ consensus workshop on methodology of diagnosis and therapy in portal hypertension. J Hepatol. 2010; 53: 762-768.

[9] Kapoor A, Dharel N, Sanyal AJ. Endoscopic diagnosis and therapy in gastroesophageal variceal bleeding. Gastrointest Endosc Clin N Am. 2015; 25: 491-507.

[10] Je D, Paik Y, Gwak GY, et al. The comparison of esophageal variceal ligation plus propranolol versus propranolol alone for the primary prophylaxis of esophageal variceal bleeding. Clin Mol Hepatol. 2014; 20: 283-290.
[11] Mallet M, Rudler M, Thabut D. Variceal bleeding in cirrhotic patients. Gastroenterol Rep. 2017; 5: 185-192.

[12] Altorjay I. Management of acute gastrointestinal bledings - practice overview. [A tápcsatornai vérzések ellátásának aktuális kérdései.] Gasztroenterol Hepatol Szle. 2018; 4: 109-119. [Hungarian]

[13] Schafer E. Gastroesophageal variceal bleeding - glypressin in focus. [Gastrooesophagealis varix vérzés - fókuszban a Glypressin.] Gasztroenterol Hepatol Szle. 2015; 1: 95-98. [Hungarian]

(Rácz Sándor dr., Budapest, Köves út 1., 1204 e-mail: 2bel@delpestikorhaz.hu)

\section{"Tuti sunt omnes unus ubi defenditur." (Ahol egy oltalmat nyer, mindenki biztonságban van.)}

A cikk a Creative Commons Attribution 4.0 International License (https://creativecommons.org/licenses/by/4.0/) feltételei szerint publikált Open Access közlemény, melynek szellemében a cikk bármilyen médiumban szabadon felhasználható, megosztható és újraközölhető, feltéve, hogy az eredeti szerző és a közlés helye, illetve a CC License linkje és az esetlegesen végrehajtott módosítások feltüntetésre kerülnek. (SID_1) 